\title{
Functional attributes of ethnically edible ectomycorrhizal wild mushroom Amanita in India
}

\section{Greeshma AA, Sridhar KR* and Pavithra M}

\author{
Department of Biosciences, Mangalore University, Mangalagangotri, Mangalore 574 199, Karnataka, India
}

Greeshma AA, Sridhar KR and Pavithra M 2018 - Functional attributes of ethnically edible ectomycorrhizal wild mushroom Amanita in India. Microbial Biosystems 3(1), 34-44.

\begin{abstract}
Functional qualities serve as valuable yardsticks towards consumer acceptability of foods and food products. This study evaluates functional properties of an ectomycorrhizal wild mushroom Amanita sp. occurring in the lateritic scrub jungles of southwestern India. Based on the ethnic knowledge, immature cooked fruit bodies of this mushroom are edible. Standard protocols were followed to evaluate functional properties of uncooked and cooked immature fruit bodies ( $\mathrm{pH}$-dependent protein solubility; least gelation concentration; water- and oilabsorption capacities; emulsion and foam properties). The protein solubility was significantly higher in uncooked against cooked samples $(\mathrm{pH} \mathrm{2-8,}<<0.05)$. Cooking has not altered the least gelation concentration (14\%). There was no significant difference between uncooked and cooked samples $(p>0.05)$ despite water-absorption and oil-absorption capacities were higher in cooked samples. The emulsion activity $(p<0.05)$, emulsion stability $(p<0.05)$, foam capacity $(p<0.01)$ and foam stability $(p>0.05)$ were higher in cooked than uncooked samples. The Principal Component Analysis (PCA) between proximal and functional properties reveals that the crude protein, total lipids and crude fibre influenced the protein-solubility, emulsion stability and foam capacity in uncooked samples. In cooked samples, the crude fibre and carbohydrates influenced all the functional properties studied except for protein solubility. It is assumed that the composition and proportion of proximal components influence the functional attributes of Amanita sp. The properties like high emulsion activity, emulsion stability and foam capacity in cooked mushroom will be useful in formulation of value-added foods or nutraceutical products.
\end{abstract}

Key words - Scrub jungles, macrofungi, ethnic food, proximal qualities, nutraceutical source.

\section{Introduction}

Functional properties characterize the structural quality, nutritional value and acceptability of food or food products. Generally, food stuffs show several functional properties like hydration properties (protein solubility, protein dispensability, water- and fat- holding capacities), surface properties (emulsion and foam), structural and textural properties (viscosity, gelation and visco-elasticity). The proximal constituents of food (proteins, carbohydrates, fats and fibre) undergo several changes during processing leading to favourable transformation in form, texture and taste of food or food product. Proteins in foods could be enzymatically modified by controlled proteolysis, which may enhance their functional properties over a wide range of $\mathrm{pH}$, ionic concentration and other processing conditions (Panyam and Kilara 1996). 
Similarly, water-holding capacity describes the ability in matrix of molecule and physically entrapped water does not flow from tissue of foods when they are cut or minced (Damodaran 1996). Foaming potential contributes to smoothness, lightness, flavour dispersions and palatability of food, while foam formation by proteins in solutions is desirable in many food applications.

A wide variety of edible macrofungi or mushrooms are rich in dietary proteins (Manjunatha et al. 2011; Wani et al. 2010). They possess several essential amino acids required for children and adults (Bernas et al. 2006; Afiukwa et al. 2015). Aremu et al. (2009) demonstrated that mushroom flours (e.g. Ganoderma spp., Omphalotus olearius and Hebeloma mesophaeum) possess properties useful in the formulation of different food products, where gelling, foaming, emulsification, flavour retention are required for desired palatability. The composition of proteins, carbohydrates, fat and fibre contents in mushrooms make them ideal non-conventional food source for diabetic, cancer and cardiac patients (Usha and Suguna 2014). Edible mushrooms could also be used as food to combat protein malnutrition owing to their capability to convert agriculture wastes into nutritionally rich food source (Lelley 1987).

Among several edible wild mushrooms available in the southwestern India, young fruit bodies of Amanita sp. constitute an ethnic food source (Karun and Sridhar 2014). It is an ectomycorrhizal fungus associated with several tree species (e.g. Acacia spp., Anacardium occidentale, Hopea ponga and Terminalia paniculata). The local people harvest tender fruit bodies of this mushroom (spherical, beak, dumble and partially opened volva) during early monsoon season (June-July) for consumption. Tender sporocarps of Amanita sp. is known for high quantities of proteins and fibre; moderate amount of carbohydrates; low total lipid content; adequate quantity of iron; favourable $\mathrm{Na}-\mathrm{K}$ ratio $(<1)$; sufficient quantities of essential amino acids; high in vitro protein digestibility; endowed with many bioactive components; possess potential antioxidant activities (Greeshma et al. 2018a, b). Hence, this study intends to fill the gap on functional qualities of uncooked and cooked tender sporocarps of Amanita sp. sampled from the lateritic scrub jungles of southwestern India to utilize for food formulations and nutraceutical products.

\section{Materials and Methods Mushroom}

Developing sporocarps of Amanita sp. were sampled from the lateritic scrub jungles of Konaje Village (Dakshina Kannada, Mangalore, India: $12^{\circ} 48^{\prime} \mathrm{N}, 74^{\circ} 55^{\prime} \mathrm{E} ; 115 \mathrm{~m}$ asl) in consultation with the local dwellers who has experience to collect during monsoon season (JuneAugust 2016) (Fig. 1). Being ectomycorrhizal, its fruit bodies are common below the canopies of several tree spcies (Acacia auriculiformis, A. mangium, Anacardium occidentale, Hopea ponga and Terminalia paniculata). Based on the morphological features, this new Amanita species roughly matches with that of Amanita marmorata (Cleland \& E.-J. Glibert) E.-J. Gilbert reported from Hawaii (Miller et al. 1996). The tender sporocarps with different shapes (spherical, oval and dumble-shaped) and partially ruptured (Fig. 1a-c) are utilized for consumption purpose by local people. Samples were made from five locations of scrub jungles with about $50 \mathrm{~m}$ apart served as replicates. The young sporocarps were rinsed in distilled water to eliminate debris and wiped with paper towel to remove surface water. Each replicate was divided into two parts and the first part was oven dried $\left(50-55^{\circ} \mathrm{C}\right)$, while the second part was cooked in a pressure-cooker with distilled water $(1: 1 \mathrm{v} / \mathrm{v})$ followed by oven drying. The dried samples were milled (mesh $\# 30)$ and flours were refrigerated in air-tight glass containers assess functional properties. 

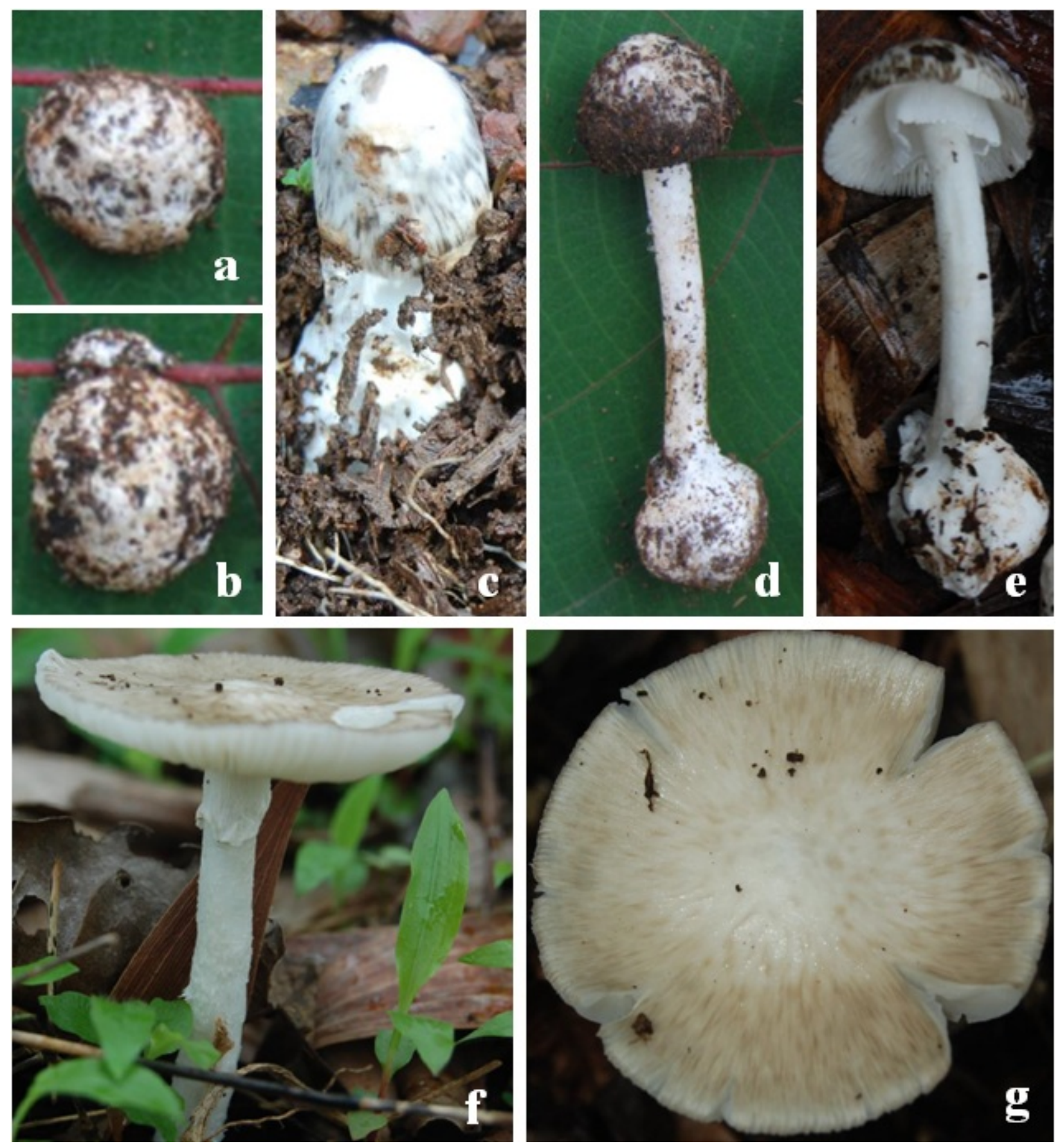

Fig. 1- Immature (a-c) (suitable for consumption), maturing (d, e) and mature (f, g) stages Amanita sp. seen in the scrub jungles of southwestern India.

\section{Protein solubility}

The protein solubility (PS) of uncooked and cooked Amanita sp. was evaluated by following the method proposed by Were et al. (1997). The flour suspension $(0.5 \%)$ in distilled water was prepared by blending and adjusting $\mathrm{pH}$ ranging from 2-10 with $\mathrm{HCl}(1 \mathrm{M})$ and $\mathrm{NaOH}$ (1M). The suspension was mixed using magnetic stirrer $\left(20 \pm 2{ }^{\circ} \mathrm{C}, 1 \mathrm{~h}\right)$. The contents were centrifuged $\left(12,000 \mathrm{rpm}, 4^{\circ} \mathrm{C}, 20 \mathrm{~min}\right)$ and the supernatant was filtered (Whatman \# 1). The amount of nitrogen in filtrate was assessed by the micro-Kjedahl method (Humphries 1956). The percentage of soluble protein was calculated as percent nitrogen in sample by multiplying by 6.25 . 


\section{Gelation}

The least gelation concentration (LGC) of the uncooked and cooked mushroom was estimated based on method outlined by Coffman and Garcia (1977). Slurry of mushroom flour ranging from $2-20 \%(\mathrm{w} / \mathrm{v})$ was prepared. An aliquot $(10 \mathrm{ml})$ was dispensed into the test tubes and incubated in boiling water bath $(1 \mathrm{~h})$ followed by cooling $\left(4^{\circ} \mathrm{C}, 2 \mathrm{~h}\right)$. The LGC was ascertained at the concentration where the sample did not slip on inverting the test tube in five replicates.

\section{Water- and oil-absorption}

The procedure proposed by Beuchant (1977) was followed to determine the waterabsorption (WA) and oil-absorption (OA) capacities of uncooked and cooked mushroom. The flour $(1 \mathrm{~g})$ was vortexed with distilled water $(10 \mathrm{ml})$ and incubated at room temperature (30 $\mathrm{min})$. The contents were centrifuged $(5000 \mathrm{rpm}, 30 \mathrm{~min})$ and the volume of supernatant was measured. To determine OA, the flour $(1 \mathrm{~g})$ was homogenised with oil $(10 \mathrm{ml})$ and processed ad described for WA. The WA and OA capacities are expressed as ml water or oil absorbed per gram of mushroom flour, respectively.

\section{Emulsion properties}

The method followed by Neto et al. (2001) was adapted to determine emulsion properties. For emulsion activity (EA), the mushroom flour $(50 \mathrm{mg})$ was suspended in distilled water $(5 \mathrm{ml})$ and vortexed with edible oil $(5 \mathrm{ml})$. The contents were centrifuged $(1100 \mathrm{rpm}, 5$ min). The height of the emulsified layer was measured to calculate the EA.

$$
\text { Emulsion activity }(\mathrm{EA})(\%)=\left(\frac{\text { Emulsified layer in } \mathrm{ml}}{\text { Total content in } \mathrm{ml}}\right) \times 100
$$

To determine emulsion stability (ES), the flour suspension was heated in water bath $\left(80^{\circ} \mathrm{C}, 30 \mathrm{~min}\right)$ before centrifugation. The height of emulsified layer was noted to calculate the ES.

$$
\text { Emulsion stability }(\mathrm{ES})(\%)=\left(\frac{\text { Emulsified layer after heating in } \mathrm{ml}}{\text { Total content in } \mathrm{ml}}\right) \times 100
$$

\section{Foam properties}

The foam properties were determined according to Coffman and Garcia (1977). For foam capacity (FC), the mushroom flour $(2 \%, \mathrm{w} / \mathrm{v})$ in distilled water was whipped vigorously ( $2 \mathrm{~min})$ in blender and poured into the measuring jar. The volume was recorded before and after homogenization to calculate the FC.

$$
\text { Foam capacity }(\mathrm{FC})(\%)=\left(\frac{\text { Volume after whipping in } \mathrm{ml}-\text { Vohme before whipping in } \mathrm{ml}}{\text { Vohume before whipping in } \mathrm{ml}}\right) \times 100
$$

The foam stability (FS) was determined by recording the volume of foam remained after incubation up to $8 \mathrm{~h}$ at room temperature to calculate $\mathrm{FS}$.

$$
\text { Foam stability }(\mathrm{FS})(\%)=\left(\frac{\text { Foam volume after } 8 \mathrm{~h} \mathrm{in} \mathrm{ml}}{\text { Initial foam volume in } \mathrm{ml}}\right) \times 100
$$




\section{Data analysis}

Student $t$-test was employed to ascertain the difference in functional properties between uncooked and cooked mushroom samples by using Statistica version 8.0 (StatSoft Inc. 2008). To find out the relationship between the functional properties with those of proximal attributes (Greeshma et al. 2018a), the principal component analysis (PCA) was performed for uncooked and cooked mushroom samples separately (SPSS version 16.0: www.spss.com).

\section{Result and Discussion}

\section{Protein solubility}

The pH-dependent protein solubility (PS) curves were followed similar pattern in uncooked and cooked mushroom samples (Fig. 2a). The solubility was higher in uncooked than cooked samples throughout the range of $\mathrm{pH}$ studied: $\mathrm{pH} 2, \mathrm{pH} 4(\mathrm{p}<0.01), \mathrm{pH} 6(\mathrm{p}<0.05), \mathrm{pH} 8$ $(\mathrm{p}<0.01)$ and $\mathrm{pH} 10(\mathrm{p}>0.05)$. In uncooked samples, the protein solubility was highest at $\mathrm{pH} 4$ followed by $\mathrm{pH} 10$, while it was highest at $\mathrm{pH} 10$ followed by $\mathrm{pH} 4$ in cooked samples. Generally, protein solubility decreases with increase of $\mathrm{pH}$ till it attains isoelectric point and thereafter increases progressively with further raise in $\mathrm{pH}$ (Adebowale et al. 2005). The uncooked Amanita sp. in our study showed considerable protein solubility at acidic ( $\mathrm{pH} 4,32 \%)$ as well as alkaline ( $\mathrm{pH} \mathrm{10,27 \% )} \mathrm{range,} \mathrm{which} \mathrm{is} \mathrm{useful} \mathrm{in} \mathrm{production} \mathrm{of} \mathrm{value-added} \mathrm{protein-rich}$ carbonated beverages as well as infant foods (Idouraine et al. 1997; Fasuyi and Aleteon 2005).

\section{Gelation}

Gelation of foodstuff is one of the important functional properties to design foodstuffs with desired texture. Lower the level of the least gelation concentration (LGC) higher the gelling ability of the protein ingredient (Akintayo et al. 2002). The LGC of uncooked as well as cooked mushroom was constant (14\%) (Fig. 2b). The LGC of Amanita sp. is comparable to Ganoderma spp. (14\%), lower than Astraeus hygrometricus (18-20\%) and higher than other mushrooms (Omphalotus olearius and Hebeloma mesophaeum: 12\%) (Aremu et al. 2009; Pavithra et al. 2017). The LGC of composite flours consisting wheat + mushroom + tapioca was as low as 2 3\% (Ekunseitan et al. 2016). It is likely the LGC of Amanita sp. could be further decreased by mixing its flour with other suitable cereal or legume flour for production of quality foodstuffs.

\section{Water- and oil-absorption}

Water-absorption (WA) capacity represents the ability of a product to associate with water under the conditions of water limitation (Singh 2001). It will be usually dependent on starch and fibre contents in the given mushroom flour. The WA ranged from $1.8-3.2 \mathrm{ml} \mathrm{g}^{-1}$ without significant difference between uncooked and cooked Amanita sp. ( $p>0.05)$ (Fig. 2c). The WA of Amanita sp. could be comparable to Astraeus hygrometricus (2.2-3.6 ml g $\mathrm{g}^{-1}$ ) and Pleurotus sajor-caju (2.4 ml g ${ }^{-1}$ ) (Prodhan et al. 2015; Pavithra et al. 2017). The oil-absorption capacity (OA) was higher in uncooked than cooked samples Amanita sp. (2.6 vs. $2.4 \mathrm{ml} \mathrm{g}^{-1}$ ) without significant difference $(\mathrm{p}>0.05)$ (Fig. 2d). The OA capacity Amanita sp. is lower compared to A. hygrometricus (1.9-2 $\mathrm{ml} \mathrm{g}^{-1}$ ) (Pavithra et al. 2017). The WA and OA capacities of protein in foodstuffs are dependent on many intrinsic factors especially amino acid composition, protein conformation and surface polarity (Suresh and Samsher 2013). The WA and OA capacities influence certain characteristics such as texture and mouth feel of foods (e.g. meat formulations, doughnuts and baked dough) (Alobo 2003). The extent of WA and OA capacities of Amanita sp. is favourable in production of food products like soups and baked products. 

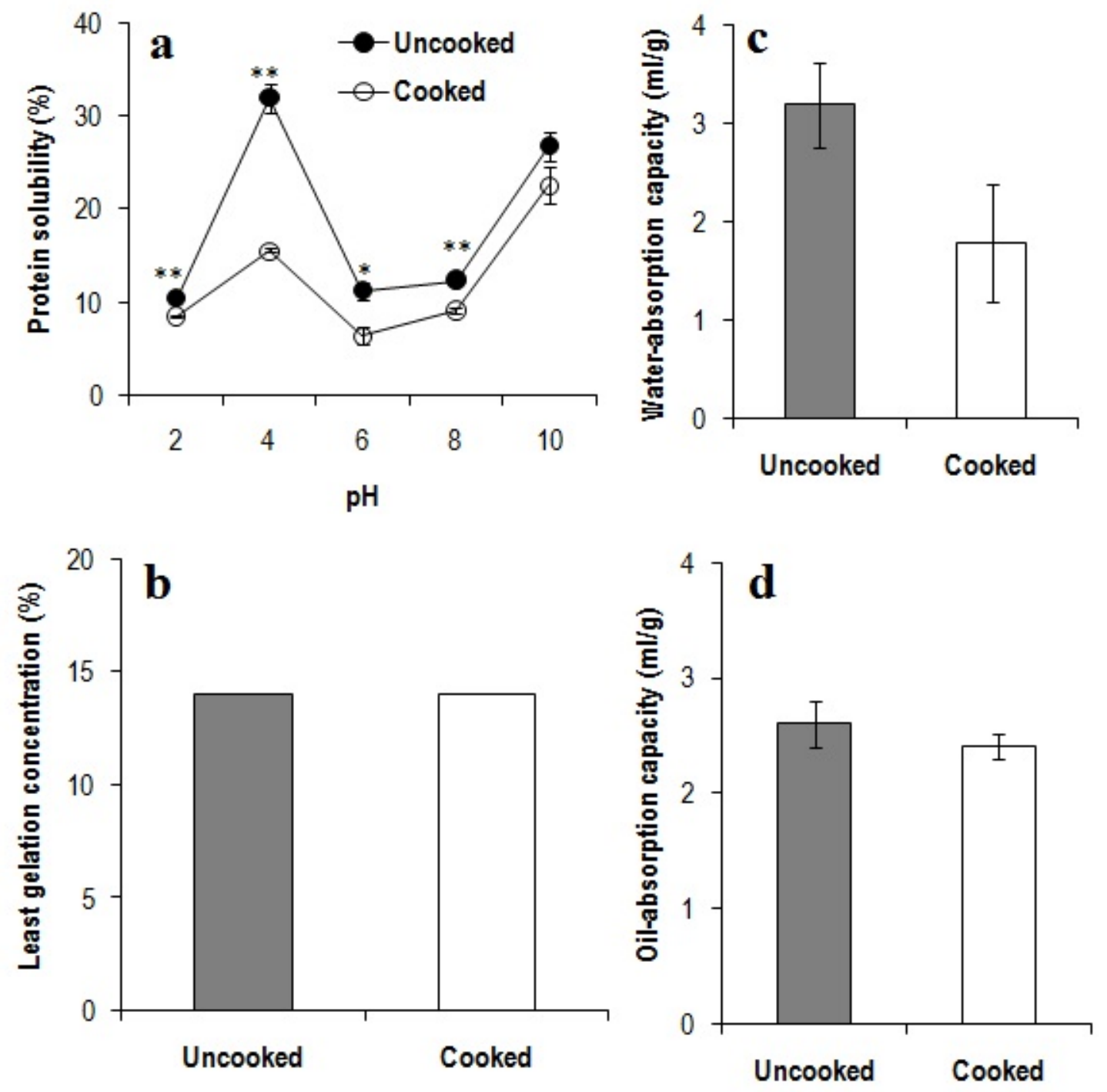

Fig. 2- Protein solubility (a), least gelation concentration (b), water-absorption capacity (c) and oil-absorption capacity (d) of uncooked and cooked tender fruit bodies of Amanita sp. ( $\mathrm{n}=5 \pm \mathrm{SD}$; t-test: $*, \mathrm{p}<0.05 ; * *, \mathrm{p}<0.01)$.

\section{Emulsion properties}

The emulsion activity is the ability of protein in foodstuffs responsible for emulsion formation as well as stability of newly formed emulsion. The emulsion capacity depends on the shape, charge and hydrophobicity of the protein molecules, neutrality of dipoles and hydration of polar groups (Zayas 1997a). The emulsion activity (EA: 12. vs. 18.4\%) (Fig. 3a) and emulsion stability (ES: 10.3 vs. $14.5 \%$ ) in our study were significantly higher in cooked than uncooked mushrooms $(\mathrm{p}<0.05)$ (Fig. 3a, b). The EA and ES are lower compared to Astraeus hygrometricus (Pavithra et al. 2017). The higher EA and ES in cooked Amanita sp. could be attributed to the higher concentration of protein in cooked than uncooked sample (Greeshma et al. 2018a). However, the EA and ES of Amanita sp. are lower than EA (47.1\%) and ES (52.2\%) of mushroom flours produced by the National Research Centre for Mushroom, Himachal Pradesh, India (Prajapati et al. 2015). 


\section{Foam properties}

Foam is a two-phase system consisting of air cells separated by a thin continuous liquid layer (Zayas 1997b). The optimum foam formation of a material depends on speed of rotation, interval of stirring and $\mathrm{pH}$ (Gassmann et al. 1987). As seen in emulsion properties, the foam capacity (FC) and foam stability (FS) (Fig. 3c, d) of Amanita sp. was higher in cooked than uncooked samples (FC, $\mathrm{p}<0.01$; FS, $\mathrm{p}>0.05)$. The FC (7.4-9.3\%) and FS (7.6-8.6\%) of Amanita sp. are comparable to Astraeus hygrometricus (Pavithra et al. 2017), bur lower than Armillaria mellea, Ganoderma spp., Hebeloma mesophaeum, Omphalotus oleariu, Termitomyces heimii and Volvariella volvacea (21.6\%. 91.7\%) (Aremu et al. 2009; Due et al. 2016a, b). The extent of FC and FS of uncooked Amanita sp. could be useful in developing formulations mainly frozen desserts, cakes, whipped toppings and ice-cream mixes (Niveditha and Sridhar 2017).
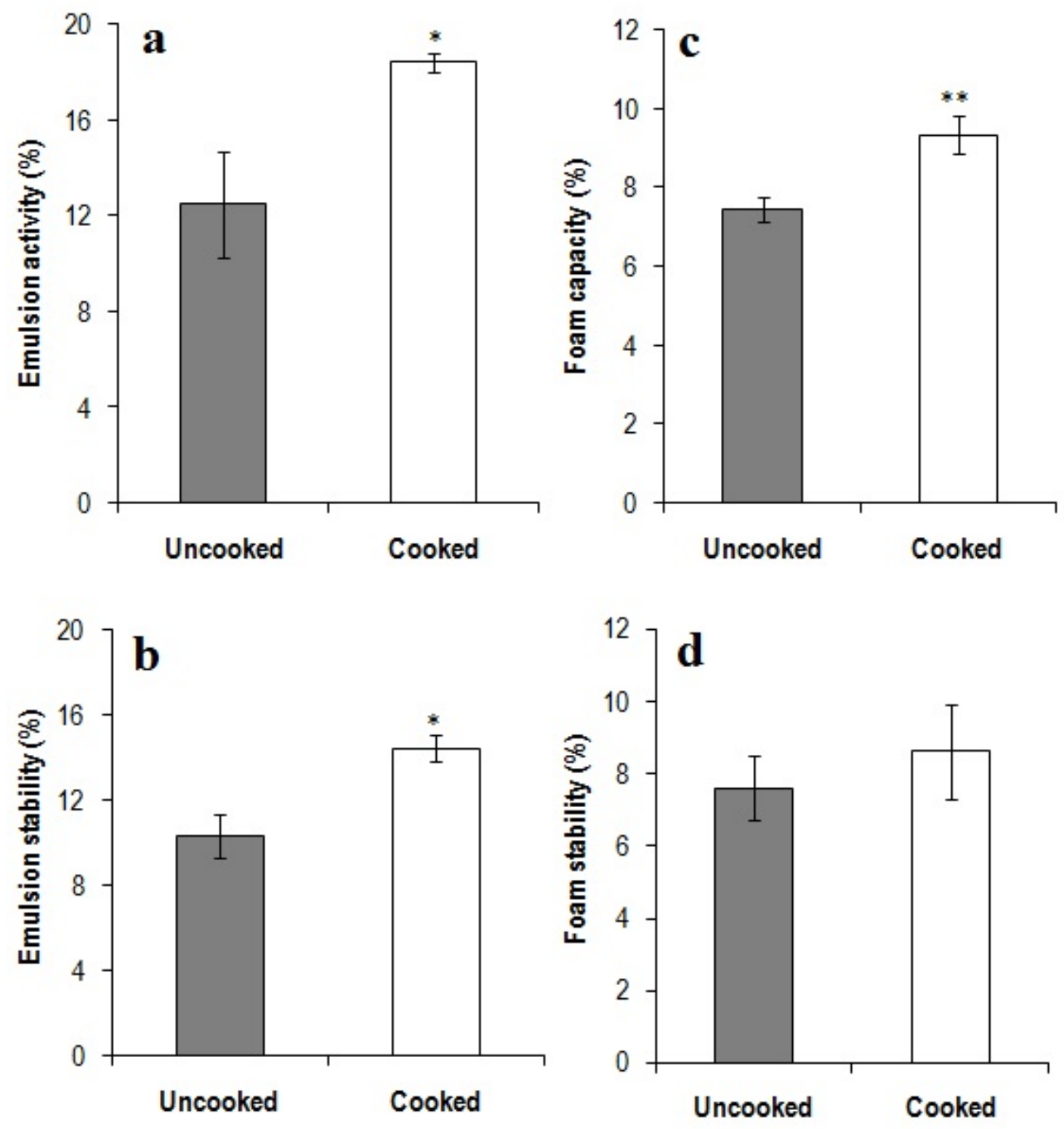

Fig. 3 Emulsion activity (a), emulsion stability (b), foam capacity (c) and foam stability (d) of uncooked and cooked tender fruit bodies of Amanita sp. $\left(\mathrm{n}=5 \pm \mathrm{SD}\right.$; t-test: $\left.{ }^{*}, \mathrm{p}<0.05 ;{ }^{* *}, \mathrm{p}<0.01\right)$. 


\section{Functional vs. proximal properties}

The PCA between proximal components and functional properties of uncooked Amanita sp. (U) resulted in two components with $100 \%$ variance (Fig. 4a). The variance for rotated score plot for component 1 and component 2 was $55.9 \%$ and $44.1 \%$, respectively. The proximal components like crude protein (CPU: $16.3 \pm 0.49$ ) and crude fibre (CFU: $7.4 \pm 0.37$ ) clustered only with protein solubility (PSU) as the first cluster at the right hand region of the plot. The emulsion stability (ESU) and foam capacity (FCU) clustered only with total lipids (TLU: $4.7 \pm 0.58$ ) as a second cluster at top of the plot. The PCA between proximal components and functional properties of cooked Amanita sp. (C) resulted in two components with $100 \%$ variance (Fig. 4b).
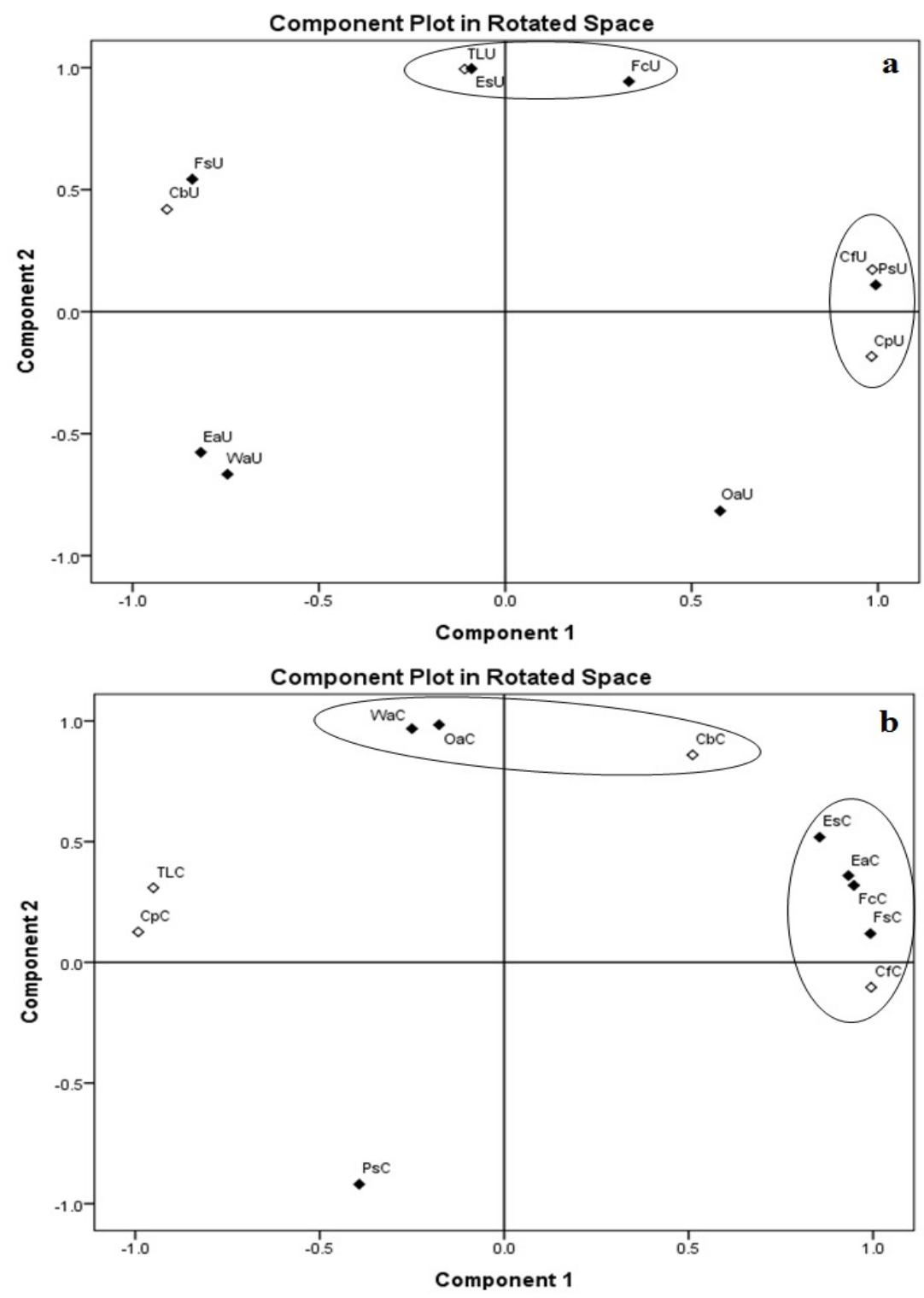

Fig. 4 Principal component analysis of uncooked (with suffix U) (a) and cooked (with suffix C) (b) tender fruit bodies of Amanita sp. between proximal components (crude protein, $\mathrm{Cp}$; total lipids, TL; crude fibre, Cf; total carbohydrates, $\mathrm{Cb}$ ) and functional properties (pH-dependant protein solubility, Ps; water-absorption capacity, Wa; oil-absorption capacity, Oa; emulsion activity, Ea; emulsion stability, Es; foam capacity, Fc; foam stability, Fs).

The variance for rotated score plot for component 1 and component 2 was $65.7 \%$ and $34.3 \%$, respectively. The crude fibre $(\mathrm{CFC}: 6.7 \pm 0.43)$ clustered with four functional properties like 
emulsion activity (ECC), emulsion stability (ESC), foam capacity (FAC) and foam stability (FSC) in the first cluster at right hand region of the plot. Water-absorption capacity (WAC) and oil-absorption capacity (OAC) were clustered with only carbohydrates (CBC: $18.5 \pm 1.6)$ at top of the plot as second cluster.

The influence of proximal properties on functional qualities differs between uncooked cooked samples of Amanita sp. In uncooked samples crude protein, total lipids and crude fibre influenced three functional properties like protein-solubility, emulsion stability and foam capacity. The crude fibre and carbohydrates of cooked samples influenced all the functional properties except for $\mathrm{pH}$-dependent protein solubility. Hence, it is predictable that instead of high quantities of proximal components, their specific composition or proportion influence the functional attributes in Amanita sp.

\section{Conclusions}

This study revealed a major difference in functional properties between uncooked and cooked edible mushroom Amanita sp. Except for $\mathrm{pH}$-dependent protein solubility, rest of the functional properties in cooked samples either significantly higher or not significantly differed. Significantly high emulsion activity and stability; significantly high foam capacity in cooked samples depicts its suitability in formulation of many value-added foodstuffs. Improved functional properties with desired proximal (protein-rich, low lipid and high fibre) and bioactive potential, cooked Amanita sp. could serve individually or additive with other raw materials in production of quality confectionaries and bakery products. It is worth attempting different methods of thermal treatment to choose the best possible combination of functional, proximal and bioactive properties in Amanita sp. to employ as a non-conventional nutraceutical source.

\section{Acknowledgements}

The first author is grateful to the Department of Science and Technology, New Delhi, India for the award of DST-INSPIRE fellowship. We are thankful to the editor and referees for constrictive suggestions to improve the presentation of the manuscript.

\section{References}

Adebowale Y.A., Henle T. and Schwarzenbolz U. 2009. Evaluation of some physicochemical and functional characteristics of proteins from Mucuna pruriens bean. Seed Science and Biotechnology, 3: 8-20.

Afiukwa C.A., Ebem E.C., Igwe D.O. and Ogah O. 2015. A comparative study of the protein and amino acid composition of cowpea and selected mushroom species in abakaliki, Nigeria. Journal of Global Biosciences, 4: 2289-2295.

Akintayo E.T., Adebayo E.A. and Arogundade L.A. 2002. Chemical composition, physicochemical and functional properties of akee (Bilphia sapida) pulp and seed flours. Food Chemistry, 77: 333-336.

Alobo A.P. 2003. Proximate composition and functional properties of Pleurotus tuberregium sclerotia flour and protein concentrate. Plant Foods for Human Nutrition, 58: 1-9.

Aremu M.O., Basu S.K., Gyar S.D., Goyal A., Bhowmik P.K. and Datta B.S. 2009. Proximate composition and functional properties of mushroom flours from Ganoderma spp., Omphalotus olearius (DC.) Sing. and Hebeloma mesophaeum (Pers.) Quél. used in Nasarawa State, Nigeria. Malaysian Journal of Nutrition, 15: 233-241.

Bernaś E., Jaworska G. and Lisiewska Z. 2006. Edible mushrooms as a source of valuable nutritive constituents. Acta Scientiarum Polonorum Technologia Alimentaria, 5: 5-20.

Beuchat L.R. 1977. Functional and electrophoretic characteristics of succinylated peanut flour protein. Journal of Agricultural and Food chemistry, 25: 258-261. 
Coffman C.W. and Garcia V.V. 1977. Functional properties and amino acid content of protein isolate from mung bean flour. Journal of Food Technology, 12: 473-484.

Damodaran S. 1996. Amino acids, peptides and proteins. In: Fennema O.R. (Ed.), Food Chemistry. Marcel Decker, New York, 321-429.

Due E.A., Koffi D.M. and Digbeu Y.D. 2016a. Biochemical and functional properties of two wild edible mushrooms (Volvariellavolvacea and Armillariamellea) consumed as protein substitutes in South Côte d'Ivoire. Journal of Chemical, Biological and Physical Sciences, 6: 1197-1206.

Due E.A., Michel K.D. and Digbeu Y.D. 2016b. Physicochemical and Functional Properties of Flour from the Wild Edible Mushroom Termitomycesheimii Natarajan Harvested in Côte d'Ivoire. Turkish Journal of Agriculture-Food Science and Technology, 4: 651-655.

Ekunseitan O.F., Obadina A.O., Sobukola O.P., Omemu A.M., Adegunwa M.O., Kajihausa O.E., Adebowale A.R.A., Sanni S.A., Sanni L.O. and Keith T. 2016. Nutritional composition, functional and pasting properties of wheat, mushroom, and high quality cassava composite flour. Journal of Food Processing and Preservation, 1:1-8.

Fasuyi A.O. and Aletor V.A. 2005. Varietal composition and functional properties of Cassava (Manihot esculenta, Crantz) leaf meal and leaf protein concentrates. Pakistan Journal of Nutrition, 4: 43-49.

Gassmann B., Kroll, J. and Cifuentes S. 1987. Determination of foaming properties of proteins. Molecular Nutrition and Food Research, 31: 321-330.

Greeshma A.A., Sridhar K.R. and Pavithra M. 2018a. Nutritional perspectives of an ectomycorrhizal edible mushroom Amanita of the southwestern India. Current Research in Environmental \& Applied Mycology, 8: 54-68.

Greeshma A.A., Sridhar K.R., Pavithra M. and Tomita-Yokotani K. 2018b. Bioactive potential of non-conventional edible wild mushroom Amanita. In: Gehlot P. and Singh J. (Eds.). Fungi and their Role in Sustainable Development: Current Perspectives. Springer (in press).

Humphries E.C. 1956. Mineral composition and ash analysis. In: Peach K. and Tracey M.V. (Eds.), Modern Methods of Plant Analysis, Volume 1. Springer, Berlin, 468-502.

Idouraine A., Yensen S. and Weber C. 1997. Tepary bean flour, albumin and globulin fractions functional properties compared with soy protein isolate. Journal of Food Science, 56: 1316-1318.

Karun N.C. and Sridhar K.R. 2014. A preliminary study on macrofungal diversity in an arboretum and three plantations of the southwest coast of India. Current Research in Environmental \& Applied Mycology, 4: 173-187.

Lelley J. 1987. Disinfection in mushroom farming-possibilities and limits. Mushroom Journal, 14: $181-187$.

Manjunathan J., Subbulakshmi N., Shanmugapriya R. and Kaviyarasan V. 2011. Proximate and mineral composition of four edible mushroom species from South India. International Journal of Biodiversity and Conservation, 3: 386-388.

Miller Jr O.K., Hemmes D.E. and Wong G. 1996. Amanita marmorata subsp. Myrtacearum - a new subspecies in Amanita section Phalloideae from Hawaii. Mycologia, 88: 140-145.

Neto, V.Q., Narain, N., Silva, J.B. and Bora, P.S. 2001. Functional properties of raw and heatprocessed cashew nut (Anacardium occidentale L.) kernel protein isolate. Molecular Nutrition and Food Research, 45: 258-262.

Niveditha V.R. and Sridhar K.R. 2017. Improvement of functional attributes of kernels of wild legume Canavalia martima by Rhizopus oligosporus. In: Gupta V.K., Zeilinger S., Filho E.X.F., Durán-Domínguez-de-Bazúa M. and Purchase D. (Eds.). Microbial Applications: Recent Advancements and Future Developments, Walter de Gruyter, Berlin, 369-388. 
Panyam D. and Kilara A. 1996. Enhancing the functionality of food proteins by enzymatic modification. Trends in Food Science and Technology, 7: 120-125.

Pavithra M., Sridhar K.R. and Greeshma A.A. 2017. Functional properties of edible mushroom Astraeus hygrometricus. Kavaka, 49: 22-27.

Prajapati R., Chandra S., Samsher N.C., Singh G.R. and Kumar S. 2015. Effect of incorporation of flours on the functional properties of composite flours. South Asian Journal of Food Technology and Environment, 1: 233-241.

Prodhan U.K., Linkon K.M.M.R., Al-Amin M.F. and Alam M.J. 2015. Development and quality evaluation of mushroom (Pleurotus sajor-caju) enriched biscuits. Emirates Journal of Food and Agriculture, 27: 542-547.

Singh U. 2001. Functional properties of grain legume flours. Journal of Food Science and Technology, 38: 191-199.

StatSoft Inc. 2008. Statistica. Version \# 8, StatSoft, Tulsa, Oklahoma.

Suresh C. and Shamsher. 2013. Assessment of functional properties of different flours. African Journal of Agricultural Research, 8: 4849-4852.

Usha S. and Suguna V. 2014. Investigation on the nutritional value of edible mushrooms viz., Auricularia polytricha and Pleurotus ostreatus. Asian Journal of Science and Technology, 5: 497-500.

Wani B.A., Bodha R.H. and Wani A.H. 2010. Nutritional and medicinal importance of mushrooms. Journal of Medicinal Plants Research, 4: 2598-2604.

Were L., Hettiarachchy L. and Kalapathy U. 1997. Modified soy proteins with improved foaming and water hydration proteins. Journal of Food Science, 62: 821-824.

Zayas J.F. 1997. Emulsifying properties of proteins. In: Functionality of Proteins in Food. Springer-Verlag, Berlin, 134-227.

Zayas, J.F. 1997. Foaming properties of proteins. In: Functionality of Proteins in Food. SpringerVerlag, Berlin, 260-309. 